\title{
The study of plant adaptation to oxygen deficiency in Saint Petersburg University
}

\author{
Tamara Chirkova ${ }^{1}$ and Vladislav Yemelyanov ${ }^{2}$ \\ 1Department of Plant Physiology and Biochemistry, Faculty of Biology, \\ Saint Petersburg State University, Universitetskaya nab., 7-9, 199034, \\ Saint Petersburg, Russian Federation \\ 2Department of Genetics and Biotechnology, Faculty of Biology, \\ Saint Petersburg State University, Universitetskaya nab., 7-9, 199034, \\ Saint Petersburg, Russian Federation
}

Address correspondence and requests for materials to: Vladislav Yemelyanov, bootika@mail.ru

\begin{abstract}
The first studies on plant anaerobiosis started at the Department of Plant Physiology at St. Petersburg University in the beginning of the $20^{\text {th }}$ century, but interest in this subject became most intensive during the investigations of the ecological plant physiology group under the supervision of Prof. T. V. Chirkova. Their first step was focused on the mechanisms of transport of gases from the aerated aboveground part of the plant to the flooded root system. Further interest shifted towards clarifying the biochemistry of respiratory metabolism, pathways of reoxidation of the reduced cofactors, and protein and lipid metabolism of plants under anoxic conditions. The group's studies have always distinguished the comparative approach, in which the changes taking place in plants differing in resistance to oxygen deficiency were analyzed. In many ways, this research was pioneering and was recognized throughout the world. For the first time the possibility of hydrogen peroxide formation in plants under total anoxia was demonstrated. The role of cell membranes in adaptation processes was revealed. Pioneering investigations distinguished the features of photosynthesis in an oxygen-free environment and the work of an antioxidant system under conditions of anoxia and post-anoxic oxidative effects. Now, the plant ecophysiology group of the Department of Plant Physiology and Biochemistry of St. Petersburg State University concentrates on the mechanisms of anaerobic signal transduction and reveals how plant hormones regulate adaptation to anoxic and post-anoxic stresses.
\end{abstract}

Citation: Chirkova, T. and Yemelyanov, oxygen deficiency in Saint Petersburg University. Bio. Comm. 63(1): 17-31. https:// doi.org/10.21638/spbu03.2018.104

Author's information: Tamara V. Chirkova, Dr. of Science in Biology, Full Professor, orcid.org/0000-0002-2315-0816; Vladislav V. Yemelyanov, PhD, Associate Professor, orcid.org/0000-0003-2323-5235

Manuscript Editor: Farida Minibayeva, Kazan Institute of Biochemistry and Biophysics, Kazan, Russia;

Guest Editor: Maria Shishova, Saint Petersburg State University, Saint Petersburg, Russia;

Received and Accepted: May 28, 2018; this contribution is a solicited history of science review, not externally peer reviewed;

Copyright: (c) 2018 Chirkova and Yemelyanov. This is an open-access article distributed under the terms of the License Agreement with Saint Petersburg State University, which permits to the authors an unrestricted distribution and self-archiving free of charge.

Funding: This work was supported by Russian Foundation for Basic Research (grants № 15-04-03090 and 18-04-00157).

Keywords: oxygen deficiency, post-anoxic stress, plant respiration, fermentation, protein and lipid metabolism, reactive oxygen species, antioxidants

\section{Introduction}

Being oxygenic photosynthetic organisms, plants are obligatory aerobes, which rely on molecular oxygen for their metabolism and survival. Nonetheless, very often they find themselves under oxygen deficiency that evolves constantly in aquatic and wetland habitats and frequently in dry lands, including agricultural, horticultural, and industrial areas. Availability of oxygen affects propagation of plant species in natural and agricultural ecosystems and has a severe economic impact. Yield losses due to lack of oxygen may reach up to 50\% (Dennis et al., 2000). The oxygen shortage usually develops because of excess water during seasonal or perennial flooding and after heavy rainfalls. It also follows ice crust formation during wintertime and appears in compact soil due to the use of heavy agricultural machinery or asphalt covering. Waterlogging of the rhizosphere and partial flooding of aboveground parts of plant lead to gradual hypoxia (deficiency of oxygen), and complete submergence leads to anoxia (total absence of the gas); 
then, restoration of normal oxygen availability during desubmergence causes post-anoxic oxidative stress.

The lack of molecular oxygen leads to inhibition of aerobic respiration, which in turn ultimately results in energy starvation. After the imposition of an anaerobic condition, the ATP level in the cell is exhausted within 1-2 min (Drew, 1997). To provide ATP for cellular metabolism, glycolysis passes into fermentation at an intensity relative to the degree of oxygen deficiency. Overconsumption of reserve sugars for respiration enhances energy starvation, particularly in hypoxia-susceptible species (Chirkova, 1988a, b; Armstrong, Brändle, and Jackson, 1994; Vartapetian and Jackson, 1997). On the other hand, stimulation of lactic fermentation and lack of ATP to energize transport ATPases account for cytosol acidification (Drew, 1997). Alcoholic fermentation generates a toxic intermediate (acetic aldehyde) and end-products (ethanol) that together with acidosis self-poison the plant under oxygen deficiency (Chirkova, 1988a, b; Crawford and Braendle, 1996; Vartapetian and Jackson, 1997; Bailey-Serres and Voesenek, 2008). In natural habitats flooding leads to low soil redox potential and production of reduced substances including $\mathrm{Fe}^{2+}, \mathrm{Mn}^{2+}, \mathrm{H}_{2} \mathrm{~S}, \mathrm{NO}_{2}{ }^{-}$ along with the products of carbon metabolism such as methane, ethane, ethylene, acetylene, acetic and butyric acid, etc. (Chirkova, 1988a, 1998; Crawford, 1989; Drew, 1997). Moreover, reestablishment of normoxic conditions triggers oxidation of these substances and synthesis of reactive oxygen, nitrogen, carbonyl and sulfur species resulting in post-anoxic injury. The growth of plants is particularly sensitive to oxygen deficiency, with root elongation greater than shoot elongation (reviewed in Chirkova, 1968a, 1988a, 1988b, 1998; Crawford and Braendle, 1996; Drew, 1997; Vartapetian and Jackson, 1997; Bailey-Serres and Voesenek, 2008; Licausi and Perata, 2009; Tamang and Fukao, 2015; Voesenek and Bailey-Serres, 2015). In plants under conditions of limited aeration, the roots are shortened, thickened, and do not form a sufficient number of root hairs. Deep-lying roots die. The majority of sensitive species demonstrate depressed shoot growth, leaf chlorosis and epinasty, finally ending with the death of the aboveground part under lack of oxygen. Nonetheless, many hydrophyte species respond to submergence by accelerated shoot growth and hyponasty of petioles and leaves, facilitating escape from the hypoxic/anoxic environment; this constitutes a so-called Low-Oxygen Escape Syndrome (LOES). Other submergence tolerant species, on the contrary, limit underwater elongation growth via a Low- Oxygen Quiescence Syndrome (LOQS). These plants react to flooding mostly by metabolic switches which are particularly rigorous under strict lack of oxygen (Chirkova, 1988a,b, 1998; Armstrong, Brändle, and Jackson, 1994; Crawford and Braendle, 1996; Bailey-Serres and Voesenek, 2008; Licausi and Perata, 2009; Tamang and Fukao, 2015; Voesenek and Bailey-Serres, 2015).
The first studies on plant adaptation to lack of oxygen were carried out at the Department of Plant Physiology at St. Petersburg University in the beginning of the $20^{\text {th }}$ century. The paper "Vremennyy anaerobioz vysshikh rasteniy. Chast' 1. Nablyudeniya nad protsessami rosta $\mathrm{v}$ beskislorodnoy srede [Temporary anaerobiosis of higher plants. Part 1. Observations on growth processes in an oxygen-free environment]" was issued in 1905 by Alexander I. Nabokikh, apprentice of Prof. Dmitri I. Ivanovski (the discoverer of tobacco mosaic virus) and Prof. Vasily V. Dokuchaev (the father of soil science) (Nabokikh, 1905). Unfortunately, the second part of this paper was never published. In 1907, Sergei P. Kostychev defended his MS thesis on "Issledovanija nad anajerobnym dyhaniem rastenij [Studies on anaerobic respiration of plants]" (Kostychev, 1907). After these episodic works, the topic did not develop for more than 50 years.

It is necessary to emphasize that the issue of oxygen shortage in plants in those years did not attract the attention of researchers all over the world, unlike the effects of water deficiency, low and high temperature, and the action of other environmental stimuli. Therefore, scientists had a terra incognita, open to research in any direction. The biology of plant respiration had been studied at the Department of Plant Physiology of St. Petersburg University since the time of Academicians Vladimir I. Palladin and Sergei P. Kostychev. But to develop the subject of respiration precisely in the direction of oxygen deficiency was advised to Prof. Stepan V. Soldatenkov by Academician Andrei L. Kursanov, who promoted the revival of interest in this field in the USSR, both in Moscow, at the Institute of Plant Physiology, and in Leningrad (now St. Petersburg), at the Department of Plant Physiology and Biochemistry of the University. As a result, in 1960, Zhao Xian Duan came out with the theme of his $\mathrm{PhD}$ thesis "Rol' list'ev u fasoli i kukuruzy $\mathrm{v}$ dyhanii kornej, lishennyh kisloroda [The role of bean and maize leaves in the respiration of roots deprived of oxygen]". These studies were continued in the works of Tamara V.Chirkova, who defended her $\mathrm{PhD}$ thesis "O roli list'ev v obespechenii kislorodom kornej rastenij razlichnyh mest obitanija [On the role of leaves in providing oxygen to plant roots of various habitat conditions]" in 1964. This subject aroused great interest, which led to the start of large-scale studies of the effect of oxygen deficiency on various aspects of plant life in Leningrad/St. Petersburg University under supervision of T. V. Chirkova.

\section{Shoot-to-root transport of oxygen as an adaptation to root hypoxia}

When the oxygen access to the roots is restricted due to waterlogging or flooding, plants try to maintain oxygen normal level required for survival in all tissues. This is 
facilitated by the development of a variety of morphological, anatomical and physiological adaptations. Many plant species are able to tolerate periods of flooding by the formation of new adventitious roots resulting in the appearance of a shallow root system (Chirkova, 1988a,b, 1998; Crawford, 1989; Armstrong, Brändle, and Jackson, 1994; Crawford and Braendle, 1996; Vartapetian and Jackson, 1997; Bailey-Serres and Voesenek, 2008; Voesenek and Bailey-Serres, 2015). Adventitious rooting is a way to replace existing roots damaged by the lack of oxygen. Emergence of adventitious roots is controlled by auxin and ethylene, and depends on their synthesis and signaling (Yemelyanov and Shishova, 2012; Sauter and Steffens, 2014; Hu et al., 2016). Roots as well as leaves and stems develop interconnected gas-filled cavities throughout the plant that provide a pathway for movement of oxygen and other gases to/from oxygendeficient organs. This special pneumatic tissue is called aerenchyma. Air spaces appear either by cell separation at the middle lamella (schizogenous aerenchyma) or by cell death and lysis of the cell wall (lysigenous aerenchyma). The performance of aerenchyma depends on plant tolerance to oxygen deficiency. It is less extensive in nonwetland species than in wetland ones (Armstrong, Brändle, and Jackson, 1994; Vartapetian and Jackson, 1997). Hydrophytes constitutively develop schizogenous aerenchyma in roots, internodes, petioles, and leaf sheaths (see Takahashi, Yamauchi, Colmer, and Nakazono, 2014). Lysigenous aerenchyma is predominantly formed in the cortex of roots of some wetland plants and many sensitive mesophyte species. Induction of aerenchyma development in non-wetland plants usually takes several hours after the imposition of oxygen shortage. Formation of lysigenous aerenchyma in maize and rice root cortex is triggered by ethylene (Armstrong, Brändle, and Jackson, 1994; Drew, 1997; Bailey-Serres and Voesenek, 2008; Yemelyanov and Shishova, 2012; Voesenek and Bailey-Serres, 2015; Hu et al., 2016).

Trees of tropical mangrove (Laguncularia sp. and Rhizophora sp.) and Amazon basin (Ficus sp.) forests have aerial prop roots that grow down from the horizontal branches, while penetrating into the soil; they are lignified and form a system of supports (Chirkova, 1988a, 1998; Voesenek and Bailey-Serres, 2015). Other mangrove trees (Avicennia sp.) and the swamp cypress (Taxodium distichum) produce specialized aerial negatively gravitropic roots called pneumatophores (Chirkova, 1968a, 1988a, 1998; Crawford, 1989). Both aerial prop roots and pneumatophores are filled with aerenchyma and covered with innumerable pores - lenticles which admit air into the plant.

Aerenchyma facilitates ventilation and gas exchange down into submerged parts of the plant and allows the plant to avoid real lack of oxygen during waterlogging or partial flooding. The key role of leaves in providing the roots of herbaceous crops (French bean, maize, tomato and potato) and trees (poplar) with oxygen during root anoxia was first shown by Prof. S. V.Soldatenkov and T.V.Chirkova's group (Soldatenkov and Zhao, 1961; Soldatenkov and Chirkova, 1963; Chirkova and Soldatenkov, 1965). It was revealed that leaves increase consumption of oxygen from the ambient atmosphere when roots suffer from anoxia. This allows anoxic roots to sustain aerobic respiration and prevent transition of glycolysis into fermentation, thus avoiding substantial accumulation of fermentation products. Leaves of nonwetland species maintain elevated oxygen consumption only for a short term (6-7 days, Soldatenkov and Chirkova, 1963); in contrast, leaves of wetland plants Glyceria maxima and Scirpus sylvaticus consume more oxygen than mesophyte species even in a normoxic atmosphere and accelerate air uptake during waterlogging (Soldatenkov and Chirkova, 1963; Chirkova, 1968a). In woody plants of the temperate zone with leafless season lasting 6-7 months, roots are supplied with atmospheric oxygen not only through the leaves, but also through the lenticles on branches (Chirkova, 1968b).

In well-adapted species aerenchyma can extend from the leaf stomata almost to the root tip, which provides aeration throughout the plant and allows oxygenation of the rhizosphere due to radial oxygen loss (Armstrong, Brändle, and Jackson, 1994; Vartapetian and Jackson, 1997). Radial oxygen loss encourages aerobic microflora and affects oxidation of anoxic soil toxins and plant mineral uptake. On the other hand, wetland species limit oxygen loss by establishing barriers in the hypodermis/exodermis by stimulation of cell wall lignification and suberinization (Nishiuchi et al., 2012; Watanabe, Nishiushi, Kulichikhin, and Nakazono, 2013) to provide oxygen delievery directly to the root tip. Moreover, this barrier may impede the penetration of soilderived toxins and gases into the roots (Armstrong, Brändle, and Jackson, 1994; Nishiuchi et al., 2012).

The ventilation system can include large reservoirs for gases; therefore, aerenchyma serves not only for supplying oxygen, but also for increasing the buoyancy that allows wetland plants to float on the surface of water (Chirkova, 1998). Besides the elimination of respiring cells, the formation of lysigenous aerenchyma leads to preservation of energy resources, oxygen consumption and deceleration of metabolism. One more important function of aerenchyma during flooding is disposal of volatile toxic fermentation intermediate and end products and soil-borne toxins (Chirkova and Gutman, 1972; Chirkova, 1988a, 1988b, 1998; Vartapetian and Jackson, 1997).

Apart from aerenchyma, the formation of aerial films on non-wettable leaf/stem surface also facilitates gas flow between the air and the flooded part of the plant (Pedersen, Rich, and Colmer, 2009; Voesenek and 
Bailey-Serres, 2015). In wetland monocots hydrophobic wax cuticle on the leaf surface enlarges the gas-water interface and allows fast $\mathrm{O}_{2}$ and $\mathrm{CO}_{2}$ diffusion, which is important not only for respiration, but also for underwater photosynthesis (Pedersen, Colmer, and Sand-Jensen, 2013). During partial and complete submergence, internal aeration of wetland species relies on underwater photosynthesis during the day and entry of oxygen from the floodwater during the night (Winkel, Colmer, Ismail, and Pedersen, 2013). Submergence-tolerant landraces of rice sustain underwater photosynthesis over a $12-\mathrm{d}$ submergence period (Winkel et al., 2014) and Amazonian palm Astrocaryum jauri - for 300 days (Armstrong, Brändle, and Jackson, 1994). Rice chloroplasts showed a complete recovery of photochemical activity after $72 \mathrm{~h}$ of oxygen deficiency, whereas wheat chloroplasts remained inactive even after shorter treatment (Chirkova, Walter, Leffer, and Novitskaya, 1995). The impairment of activity of Photosystem II appeared earlier than in Photosystem I, especially in sensitive mesophytes (wheat), indicating that non-wetland species are incapable of implementation of effective underwater photosynthesis (Chirkova, Walter, Leffer, and Novitskaya, 1995). Thus, the leaves of resistant plants, in contrast to those of non-resistant ones, not only ensure their ventilation by enhancing the absorption of oxygen from the ambient atmosphere during hypoxia, but also are able to keep its supply for a long time through the process of underwater photosynthesis.

The mechanisms listed above (adventitious shallow rooting, aerenchyma formation, gas films and underwater photosynthesis) represent a strategy to avoid root hypoxia/anoxia during soil waterlogging and partial flooding. But these adaptations become ineffective when the plant is totally submerged.

\section{Acceleration of shoot growth as an adaptation to complete submergence}

Fast underwater growth of shoot axial organs like coleoptiles, stem internodes, and petioles has been demonstrated in a wide variety of wetland species of different taxonomical origin displaying low-oxygen escape syndrome (LOES). The growth is stimulated either by cell elongation with little or no change in their division, e.g., in Callitriche platycarpa, Hydrocharis morsus-ranae, $R a$ nunculus sceleratus, Rumex crispus and R.palustris (reviewed in Peeters et al., 2002; Yemelyanov and Shishova, 2012), or by cell proliferation and subsequent elongation, like in deepwater rice (Kende, van der Knaap, and Cho, 1998), Nymphoides peltata, Ranunculus repens and R.pygmaeus (Yemelyanov and Shishova, 2012).

LOES is strictly regulated by the plant hormonal system. Submergence induces synthesis and physical entrapment of ethylene inside plant tissues (reviewed in Armstrong, Brändle, and Jackson, 1994; Vartapetian and Jackson, 1997; Kende, van der Knaap, and Cho, 1998; Bailey-Serres and Voesenek, 2008; Yemelyanov and Shishova, 2012; Voesenek and Bailey-Serres, 2015; $\mathrm{Hu}$ et al., 2016). In well-adapted wetland species, ethylene accumulation occurs only within the first hours of submergence and never reaches a high concentration like in non-tolerant mesophyte species. This plant hormone is thought to be the master signal for rearrangement of hormone crosstalk during flooding stress. Ethylene stimulates a decrease in ABA levels in deepwater rice coleoptiles, internodes and petioles of Rumex palustris by repressing $\mathrm{ABA}$ biosynthesis and enhancing $\mathrm{ABA}$ catabolism. Plants which are more susceptible to oxygen deprivation accumulate a higher amount of $\mathrm{ABA}$ during submergence or total anoxia (Yemelyanov and Chirkova, 1996; Yemelyanov, 1998; Emel'yanov, Kirchikhina, Lastochkin, and Chirkova, 2003; Hu et al., 2016). The ethylene-induced drop in ABA concentration in LOES species relieves the inhibition from synthesis of bioactive GAs, which mediates the majority of ethylene effects on fast underwater shoot growth. This interaction between ethylene, ABA, and GA accelerates the growth of stems and leaf petioles by stimulating cell elongation and division. Promotion of shoot extension by hormone rearrangement during submergence is linked with cell wall loosening provided by stimulation of pectinase, xylanase, xyloglucan endotransglucosylase/hydrolase, and expansins (Bailey-Serres and Voesenek, 2008; Yemelyanov and Shishova, 2012; Voesenek and Bailey-Serres, 2015; Hu et al., 2016). These proteins are also involved in aerenchyma formation. In some plants, underwater growth is supported by accumulation of auxin, caused by submergence either in an ethylene-dependent or -independent manner (Yemelyanov and Shishova, 2012; Voesenek and Bailey-Serres, 2015; Hu et al., 2016). Ethylene-auxin interaction regulates epi- or hyponastic response of leaves and formation of adventitious root system depending on plant tolerance (Yemelyanov and Shishova, 2012; Hu et al., 2016). Carbohydrates required for new cell wall synthesis and fast growth are provided by underwater photosynthesis and by the mobilization of starch reserves via an increase in $\alpha$-amylase activity (Bailey-Serres and Voesenek, 2008; Voesenek and Bailey-Serres, 2015). These responses allow plants to reach water surface with the shoot tips extending above the water surface, escaping from the oxygen-deficient environment; they exchange gases for respiration and photosynthesis, which finally results in plant adaptation and survival. Non-tolerant mesophyte species accumulate relatively high amounts of ethylene and $\mathrm{ABA}$ and decrease the levels of growth stimulators (GA and auxin) under lack of oxygen, leading to stimulation of senescence, epinasty, leaf abscission, and finally plant death (Yemelyanov and Shishova, 2012).

Furthermore, ethylene is supposed to be not only the master signal for regulation of hormone crosstalk 
during flooding stress, but also for choice of adaptation strategy and sensing of oxygen level. Interestingly, the largest group constituting about $20 \%$ of all transcription factors up-regulated by oxygen deficiency in Arabidopsis thaliana belongs to Apetala 2-like Ethylene Responsive Factors group VII (ERF-VIIs, Licausi and Perata, 2009; Licausi et al., 2011). There are five genes encoding ERF-VIIs in A. thaliana. Three of these are constitutively expressed Related to AP2 12 (RAP2.12), RAP2.2 and $R A P 2.3$ and up-regulated by ethylene, and the other two $\underline{H} Y P O X I A \underline{R} E S P O N S I V E \underline{E} R F \underline{1 / 2}$ (HRE1/2) are highly induced by oxygen deprivation (Voesenek and Bailey-Serres, 2015). These ERF-VIIs bear a conserved Met-Cys N-terminal motif that is targeted to constitutive proteasomal degradation through the $\mathrm{N}$-end rule pathway under normoxia and due to interaction with reactive oxygen and nitrogen species (Banti et al., 2013). Oxygen deprivation leads to stabilization of the ERFVIIs, RAP2.12 migrates into the nucleus and activates transcription of hypoxia-responsive genes, including HRE1/2 and PDC encoding pyruvate decarboxylase (Voesenek and Bailey-Serres, 2015).

Two major adaptive responses, LOES and LOQS, are primarily governed by the multigenic $\underline{S} N O R \underline{K} E L$

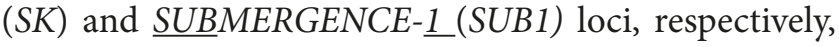
both of which encode ERFVIIs (Bailey-Serres and Voesenek, 2008; Nishiuchi et al., 2012; Banti et al., 2013; Tamang and Fukao, 2015; Voesenek and Bailey-Serres, 2015; Hu et al., 2016). The SNORKEL locus encodes the two ERF-VII genes. Ethylene-triggered induction of SK1 and SK2 during submergence upregulates expression of the GA20 oxidase gene responsible for GA biosynthesis, and promotes fast underwater growth. The SUBMERGENCE-1 locus encodes two ERF-VII genes, Sub1B and Sub1C in all japonica and some submergence-intolerant indica rice cultivars. In the tolerant indica cultivars using LOQS, like FR13A and Kurkaruppan, which the Sub1 locus was first isolated from, three ERF-VII genes are present, with addition of Sub1A. Sub1A and Sub1C transcripts levels are upregulated by submergence and ethylene (Fukao, Xu, Ronald, and Bailey-Serres, 2006) and downregulated by ABA (Fukao and Bailey-Serres, 2008). Sub1A confers tolerance to prolonged complete submergence in lowland rice. It dampens ethylene production and represses ethyleneand GA-mediated responses in cell elongation and carbohydrate breakdown, including expansin and amylase genes expression. On the other hand, the Sub1C gene is upregulated by submergence, ethylene and GA, and it stimulates shoot elongation in LOES rice. In quiescenttolerant rice cultivars, Sub1C is repressed by Sub1A (Fukao, Xu, Ronald, and Bailey-Serres, 2006; Tamang and Fukao, 2015). Sub1A was reported to increase the accumulation of the signaling proteins $\underline{\text { Slender Rice- }}$ $\underline{1}(\mathrm{SLR} 1)$ and SLR1 Like-1 (SLRL1), which repress GA signaling (Fukao and Bailey-Serres 2008), possibly via stimulation of brassinosteroid signaling pathway and with transcriptional activation of GA2ox7, which catabolizes GA, thus reducing the levels of endogenous active GAs (Schmitz et al., 2013). At the same time, Sub1A induces metabolic adaptation by upregulation of genes, encoding pyruvate decarboxylase and alcohol dehydrogenase $(\mathrm{ADH})$ involved in alcoholic fermentation $(\mathrm{Fu}-$ kao, Xu, Ronald, and Bailey-Serres, 2006). Thus, Sub1A blocks LOES and stimulates LOQS, transiently limiting growth, which allows the plant to keep its energy and capacity for regrowth upon desubmergence. The same LOQS based primarily in metabolic adaptation is used by dormant rhizomes of wetland species. The study of metabolic adaptations of plants to hypoxia and anoxia was the main subject of study of Prof. T. V.Chirkova's group in Leningrad/St. Petersburg University.

\section{Alteration of metabolism as an adaptation to total hypoxia and anoxia}

The metabolic adaptations of plants to oxygen deficiency affect various aspects of cellular metabolism, but due to the nature of the stressor, they involve mainly respiration adjustments. When the oxygen level drops, it results in inhibition of cytochrome c oxidase (COX, complex IV) activity and suppression of aerobic respiration. Disturbance of aerobic respiration takes place after a more prolonged period of oxygen deprivation, and recovery of respiration rate after anoxia occurs earlier in seedlings of a tolerant plant (rice) than of a non-resistant one (wheat, Chirkova and Nastinova, 1975a). This corresponds to the less injury and better maintenance of cell structures involved in respiration in well-adapted species. Low respiration rate is characteristic for wetland species even under normoxic conditions (Chirkova, 1988a, b, 1998). It is specific for floating and underwater leaves of hydrophytes compared to aerated abovewater ones, for rhizomes of aquatic plants, for the roots of resistant plants (Salix alba, Glyceria maxima) in contrast to sensitive ones (Populus petrowskiana, Phaseolus vulgaris) (Chirkova and Petrova, 1971; Chirkova and Khazova, 1974). Low respiration rate indicates moderate consumption of oxygen, which allows the plant to maintain the intensity of respiration almost unaltered even under mild oxygen deficiency.

The inhibition of aerobic respiration by oxygen deficiency leads to a depleted ATP level, and providing ATP becomes the major problem for respiratory metabolism. Solution of this problem is mainly accounted for by acceleration of glycolysis, subsequently turning into lactic and ethanolic fermentation, which was shown in our work (Chirkova, 1988a,b, 1998). However, the rate of transition from aerobic metabolism, as well as the dynamics of glycolysis, differs significantly in plants 


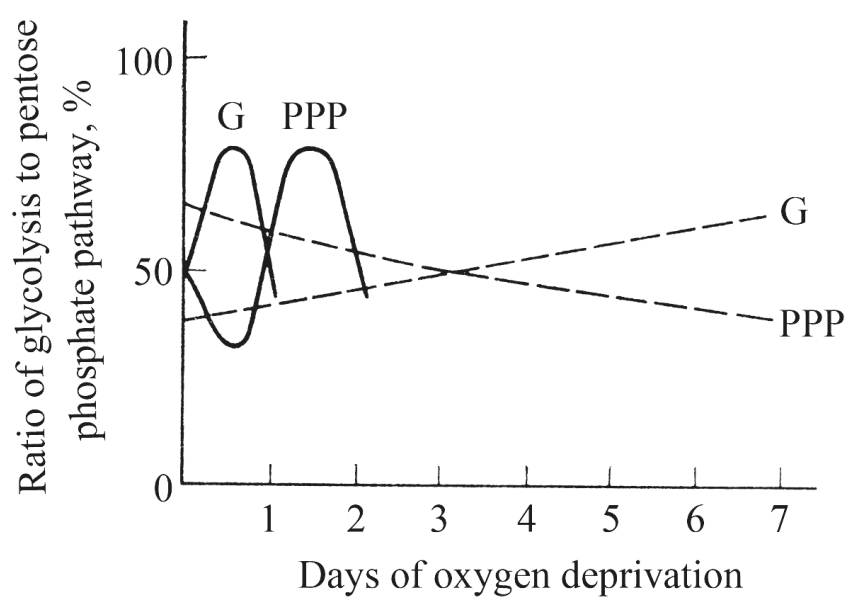

Fig. 1. Scheme of alteration of respiratory pathways ratio under oxygen deprivation in non-resistant (solid lines) and resistant (dashed lines) plant species. G - glycolysis, PPP - pentose phosphate pathway (Chirkova, 1988a).

contrasting in resistance to hypoxia. A fast short-term increase of glycolytic activity was observed in non-resistant plants (wheat, Phaseolus vulgaris, poplar) already in the first hours of anaerobic exposure (Fig. 1). In adapted species (rice, Glyceria maxima, willow) activation of this process was less intensive and took a longer time, which determined a more reliable supply of energy (Chirkova and Petrova, 1971; Chirkova and Nastinova, 1975b; Chirkova and Zhukova, 1987; Crawford, 1989).

Sufficient substrate availability is required for efficient glycolysis operation. Since glycolysis provides only 2 moles of ATP per 1 mole of glucose, it leads to an overconsumption of sugars, especially in non-wetland species (Chirkova, 1973; Zhukova, 1987). Many resistant plants of aquatic and semiaquatic habitat accumulate a significant amount of carbohydrates in the rhizomes (up to $50 \%$ of their dry weight, Armstrong, Brändle, and Jackson, 1994; Vartapetian and Jackson, 1997; BaileySerres and Voesenek, 2008; Licausi and Perata, 2009). Moreover, carbohydrate supply is important for both adaptive strategies, LOES and LOQS (Bailey-Serres and Voesenek, 2008; Voesenek and Bailey-Serres, 2015). In experiments with excised organs (coleptiles, stem sections, roots), exogenously applied sugars is absolutely required for anoxic tolerance (Chirkova, 1988a; Vartapetian and Jackson, 1997). However, the availability of carbohydrate reserves is not sufficient for the survival of non-resistant plants. Many of them are incapable of mobilizing polysaccharides due to the absence of expression of genes encoding starch phosphorylase and $\alpha$-amylase during anoxia action. However, seeds and rhizomes of hydrophytes do mobilize reserves during hypoxic/anoxic germination (see Licausi and Perata, 2009).

Another "bottleneck" of metabolism during oxygen shortage is reoxidation of NADH reduced in glycolysis,

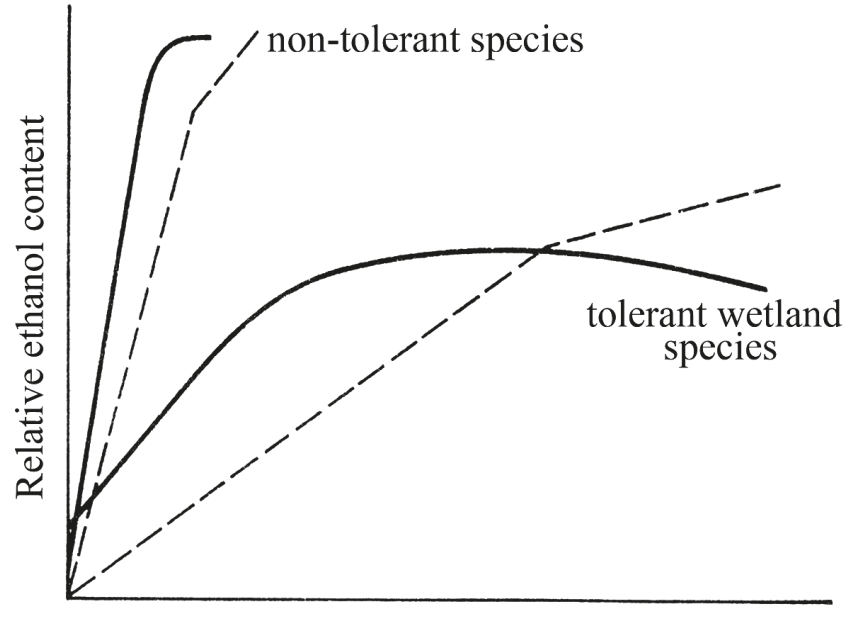

Duration of oxygen lack

Fig. 2. Scheme of ethanol accumulation in plant tissues (solid lines) and ambient medium (dashed lines) under oxygen deprivation (Chirkova, 1988a).

since its oxidation in the mitochondrion is blocked. This is generally achieved through fermentation pathways. Both fermentations are stimulated by an increase of activity of their enzymes (lactate dehydrogenase, pyruvate decarboxylase and alcohol dehydrogenase) at the steric, transcriptional and translational level (Chirkova and Petrova, 1971; Chirkova, 1973, 1988b; Chirkova, Khazova, and Astafurova, 1974; Nastinova and Chirkova, 1978; Chirkova, Nastinova, and Zhukova, 1978). Activation of fermentation as well as glycolysis occurs earlier and more intensely in non-resistant mesophyte species compared to in adapted hydrophytes (Chirkova, 1988a,b, 1998; Crawford, 1989), resulting in the synthesis of intermediate and end-products that contribute to toxicity (acetic aldehyde, ethanol) and cytosolic acidification (lactate) under lack of oxygen. Moreover, glycolytic flux to lactate is minor compared with that to ethanol, especially in wetland species, while non-resistant plants stimulate lactic fermentation during oxygen deficiency to a higher extent (Chirkova, 1973). Nonetheless, ethanolic fermentation is the major pathway throughout the plant kingdom. Non-tolerant plants accumulate a higher amount of ethanol followed by disposal of ethanol into the rhizosphere and flooded water within the first hours-days of oxygen deprivation (Fig. 2). Well-adapted species produce less alcohol and lactate for a longer period of oxygen shortage due to limiting of metabolism, and they remove more end products into the environment - both into the ambient solution and via aerenchyma into the air during root hypoxia (Chirkova and Gutman, 1972; Chirkova, 1978; Chirkova, Nastinova, and Semenova, 1978). Besides deceleration of metabolic rate and disposal of toxic products, toxic metabolite accumulation may be avoided by alteration of metabolic pathways leading to substances other than ethanol or 


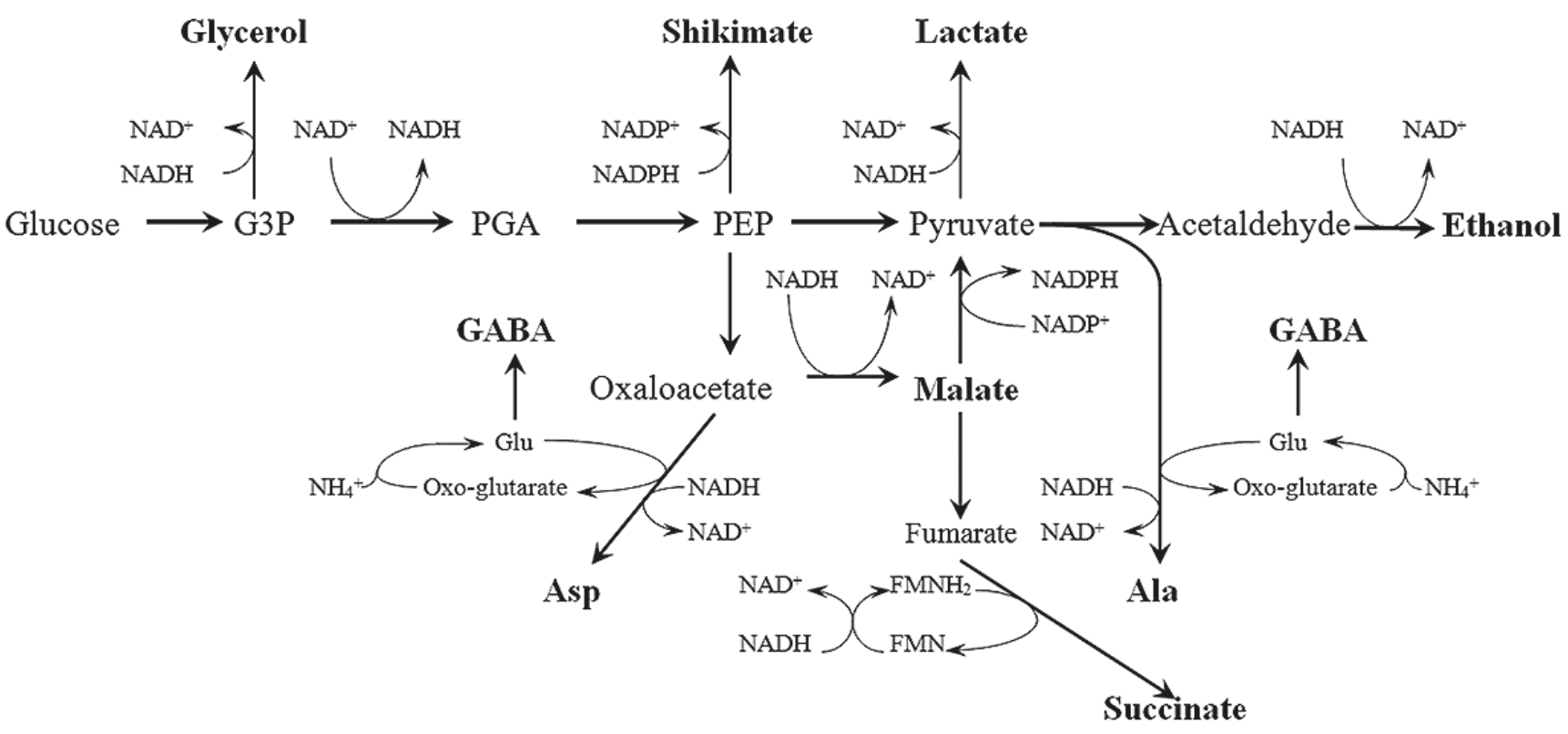

Fig. 3. Scheme of NADH reoxidation pathways involved in plant metabolic adaptation under partial or total oxygen deficiency (Crawford, 1978; Chirkova, 1988b, 1998, with modifications). Bold arrows indicate the major glycolytic pathway passing into ethanolic fermentation. Compounds indicated in bold correspond to the main metabolites of resistant wetland plants during hypoxia. G3P — glyceraldehyde 3-phosphate, GABA — y-aminobutyric acid, PEP - 2-phosphoenolpyruvate, PGA - 3-phosphoglyceric acid.

lactate. Many tolerant plants are capable of rerouting glycolytic intermediates to alternate end products such as malate, succinate, glycerol, Ala and GABA (Fig. 3). Production of these alternative hypoxic metabolites allows the plant to reoxidize $\mathrm{NADH}$ into $\mathrm{NAD}^{+}$, which is required for glycolysis and prevents cell toxicity during hypoxia. Importantly, accumulation of Ala and GABA copes with cytosolic acidosis during oxygen deprivation (Bailey-Serres and Voesenek, 2008; Licausi and Perata, 2009). The first step in the pathway is reversal of the dicarbonic part of the Krebs cycle converting oxaloacetate into malate (Crawford, 1978; Chirkova, 1988a, 1998) due to activation of NAD-dependent malate dehydrogenase (Chirkova, Barzhinkova, Barkova, and Magomedov, 1984) and then into fumarate and succinate (Chirkova and Nastinova, 1977; Chirkova, Barkova, Barzhinkova, and Magomedov, 1985). Succinate accumulation is not related to the glyoxylate cycle, since isocitrate lyase is inhibited by oxygen deprivation in plant tissues irrespectively of their tolerance (Chirkova and Grevnina, 1982). Later research demonstrated that reversal of the Krebs cycle occurs in resistant plants only during hypoxia, and severe anoxia provokes mostly activation of fermentation (Kulichikhin, Kurchakova, and Chirkova, 2000; Kulichikhin, Chirkova, and Fagerstedt, 2009). Nonetheless, hypoxia-resistant plants (rice, willow) may tolerate rather high concentrations of ethanol (Chirkova and Semenova, 1979; Chirkova, Barzhinkova, and Hoang, 1980) and incorporate it into metabolism during hypoxia, and especially post-hypo/anoxia (Chirkova, 1975, 1978). Plants also may prevent forma- tion of toxic end-products by using other respiratory pathways such as oxidative pentose phosphate pathway (PPP). The pattern of its stimulation depends on plant tolerance to oxygen deprivation. Short-term supression of PPP activity occurs with simultaneous acceleration of glycolysis in non-resistant plants during the first hours of oxygen deficiency (Fig. 1). Later, when the glycolytic pathway slows down, PPP transiently activates. Wetland species are characterized by gradual long-term activation of glycolysis and the same stopping of PPP under hypoxia (Chirkova and Nastinova, 1975b; Chirkova, 1988a,b, 1998). PPP generates reduced NADPH and requires its reoxidation, which may be performed via condensation of erythrose 4-phosphate with phosphoenolpyruvate to produce shikimate (Fig. 3, Crawford, 1978).

As previously discussed, oxygen shortage affects the electron transfer chain in the mitochondria, which is determined by the high sensitivity to oxygen of the energy and transport processes in the mitochondria. Oxygen deprivation causes blockage of the electron transport chain in plants grown under normal aeration. However, its components retain some potential activity, which is renewed after the return of oxygen into the environment. The ability to restore respiration in resistant plants remains even after a longer period of anaerobiosis in comparison with non-resistant ones (Chirkova, Dragunova, and Burgova, 1977; Chirkova and Karpenko, 1981). Moreover, involvement of alternative cyanideresistant oxidase in plant adaptation to oxygen deprivation was revealed (Chirkova and Kovalenko, 1982); this 
was confirmed later by analysis of $A O X$ gene expression (see Bailey-Serres and Voesenek, 2008). High capacity of reparation of aerobic respiration of adapted species is determined by stability of cell membranes (Chirkova, 1983) and mitochondrial proteins (Hoang et al., 1979; Chirkova and Hoang, 1981; Chirkova, Saakov, Semenova, and Avdeeva, 1993), and adenylate kinase activity (Chirkova, Zhukova, and Ivanova, 1984). All together these processes provide sufficient ATP synthesis (Zhukova, Chirkova, and Tretyakov, 1984; Chirkova, 1988b; Kulichikhin, Aitio, Chirkova, and Fagerstedt, 2007) and effective maintainence of intracellular $\mathrm{pH}$ (Chirkova, Verzilin, Barzhinkova, and Petryaevskaya, 1981; Kulichikhin, Aitio, Chirkova, and Fagerstedt, 2007) in wetland plants during oxygen deprivation in comparison to non-resistant plants.

During submergence oxygen availability is limited and plants have to use other acceptors of electrons and protons; this is generally called "anoxic endogenous oxidation" and "nitrate respiration" in the case of nitrate. Treatment of plants with nitrates favors anoxic metabolism and adaptation of poplar, willow, cereals (Chirkova, 1971; Chirkova and Benko, 1973; Belonogova and Chirkova, 1995), Amaranthus caudatus, A.cruentus and A.edulus (Belonogova and Chirkova, 1994; Belonogova, Chirkova, and Zabruskov, 1995). Higher uptake of nitrate, activation of nitrate reductase, accumulation of ammonium and amino acids (mostly Ala, Glu and GABA, Licausi and Perata, 2009) occurs predominantly in resistant plants (Chirkova, 1971, 1988b; Belonogova and Chirkova, 1994, 1995). Importantly, the nitrate reductase in the cytosol reduces nitrate into nitrite while simultaneously oxidizing $\mathrm{NAD}(\mathrm{P}) \mathrm{H}$. Then nitrite enters the mitochondrion and serves as an alternative terminal electron acceptor at sites of cytochrome bcl complex (III) and cytochrome coxidase (COX, complex IV), producing nitrogen oxide that is involved in anoxic signaling and can be converted in the cytosol by hypoxically induced non-symbiotic haemoglobin back to nitrate. The latter is again reduced to nitrite by nitrate reductase, forming the so-called haemoglobin/nitric oxide cycle (Igamberdiev and Hill, 2009). This cycle not only reoxidizes $\mathrm{NAD}(\mathrm{P}) \mathrm{H}$ but also provides proton pumping at the COX site sufficient for ATP synthesis. Therefore, in case of nitrate we may truly call this metabolic pathway "nitrate respiration". Anoxic endogenous oxidation also includes the hydrogenation of double and triple bonds of unsaturated compounds, for example, of carotenes, terpenoids and polyunsaturated fatty acid residues in cell lipids (Chirkova, 1988a,b, 1998).

All of the above mentioned changes in plant growth and respiratory pathways during oxygen deficiency are due to alterations of protein metabolism. Like any other stressor, oxygen shortage negatively affects protein content, since its synthesis is inhibited and degradation is stimulated (Chirkova, 1988a,b, 1998; Chirkova and Voitsekovskaya, 1999b). However, there are significant differences between proteolysis and protein synthesis in plants depending on their resistance to submergence. Decrease of protein content occurs in resistant plants much more slowly and after a stronger and more prolonged oxygen deprivation than in non-resistant ones (Chirkova, Nastinova, and Zhukova, 1978; Chirkova and Hoang, 1981). Moreover, proteins from energy-producing organoids (mitochondria and chloroplasts) of tolerant species manifest higher stability (Chirkova and Hoang, 1981; Chirkova, Saakov, Semenova, and Avdeeva, 1993; Chirkova, Novitskaya, Walter, and Leffer, 1995; Chirkova, Walter, Leffer, and Novitskaya, 1995). At the same time, the number of molecular forms of cytosolic and organellar proteins increases (Chirkova and Hoang, 1981), which may indicate both the degradation of more complex proteins and the synthesis of new proteins during oxygen deficiency. The idea of the possibility of protein synthesis in an oxygen-free environment was developed and experimentally confirmed only in the mid-1970s. We were among the first who demonstrated the crucial role of protein synthesis in activation of peroxidase (Chirkova and Sokolovskaya, 1976), LDH and ADH (Chirkova, Nastinova, and Zhukova, 1978; Nastinova and Chirkova, 1978), malate dehydrogenase (Chirkova, Barzhinkova, Barkova, and Magomedov, 1984), nitrate reductase (Chirkova, 1988b) and nonhistone chromatin proteins (Chirkova, Surodeeva, and Semenova, 1986; Voitsekovskaya and Chirkova, 1992; Voitsekovskaya, Badyina, and Chirkova, 1993; Chirkova and Voitsekovskaya, 1999a) in rice, Glyceria maxima, and other wetland species during hypo/anoxia. It is now generally accepted that lack of oxygen induces synthesis of anaerobic stress proteins belonging to the signal transduction network, to enzymes of the respiratory pathways, carbohydrate mobilization, nitrogen metabolism, cell wall loosening, and antioxidant defence (Vartapetian and Jackson, 1997; Chirkova and Voitsekovskaya, 1999b). Proteomic studies revealed from about 30 to 70 upregulated proteins in different plants under oxygen shortage (Chen et al., 2014; Yin, Sakata, Nanjo, and Komatsu, 2014).

Stability of lipids also plays an important role in providing plant resistance to oxygen deficiency. Phospholipids and other constituents of cell membranes are of particular interest. Oxygen deficiency lowers the content of total lipids and phospholipids, dampens lipid biosynthesis (Hoang, Sinyutina, and Chirkova, 1979; Sinyutina, Hoang, and Chirkova, 1979; Chirkova et al., 1989; Chirkova, Sinyutina, Smetannikova, and Krynkina, 1989) and stimulates lipid degradation, leading to accumulation of free fatty acids (Valyavskaya, Sinyutina, and Chirkova, 2000, 2002). Degradation of lipids and free fatty acids is facilitated by lipid peroxidation 
(LPX). LPX usually occurs in normal unstressed conditions and drastically increases upon stress action. LPX is activated mainly after reoxygenation, when the plant returns to aeration. But we demonstrated LPX even in an oxygen-free environment (Chirkova and Blokhina, 1991). The anoxia-induced lipid loss is less intense in resistant plants than in non-resistant ones (Hoang, Sinyutina, and Chirkova, 1979; Valyavskaya, Sinyutina, and Chirkova, 2000) even after treatment with ethanol (Chirkova, Hoang, and Sinyutina, 1980). Sterol content increases upon oxygen deficiency (Valyavskaya, Sinyutina, and Chirkova, 2000), particularly in mitochondria of non-resistant plants (Valyavskaya, Sinyutina, and Chirkova, 2002). In contrast, mitochondrial membranes accumulate less sterols and maintain phospholipid level in wetland species during oxygen deficiency. Lipids of photosynthetic membranes demonstrated even higer stability, again in well-adapted plants. Imposition of anoxia with light results in sustaining of chloroplast phospholidid (Chirkova, Gobedzhishvili, Hakala and Sinyutina, 1991a) and galactolipid (Chirkova, Gobedzhishvili, Hakala, and Sinyutina, 1991b) biosynthesis in the shoots of rice seedlings. Surprisingly, the effect of darkness on the chloroplast lipids was more dramatic than the effect of anoxia. If anoxic treatment is accompanied by illumination, this permits photosynthesis and diminishes the negative aftermath of oxygen deficiency. Besides the effect on lipid synthesis and degradation, the saturation of the fatty acid component of phospholipids undergoes significant changes, since it is responsible for the physico-chemical characteristics and function of the membranes. Oxygen deprivation leads to a gradual increase of the fraction of saturated and monounsaturated fatty acid residues, while the fraction of polyunsaturated fatty acid residues is exhausted (Blyudzin, Hoang, and Chirkova, 1980; Chirkova, Hoang, and Blyudzin, 1981; Blyuzdin, Barskiy, Chirkova, and Sokolova, 1986). This process takes part in anoxic endogenous oxidation for $\mathrm{NAD}(\mathrm{P}) \mathrm{H}$ recycling. In wetland species, saturation of membrane lipids occurs under stronger oxygen deficiency than in non-resistant ones, especially in mitochondria (Chirkova, Hoang, and Blyudzin, 1981).

Thus, the rearrangements of both protein and lipid metabolism are related to the needs to cope with the requirements of plant respiratory pathways under oxygen deficiency. They are interconnected to the integral role of cell membranes in plant resistance to adverse impacts. The integrity and functional activity of the plasma membrane, tonoplast, mitochondrial and chloroplast membranes of adapted plants maintain longer in an oxygen-deficient environment (Chirkova, 1983, 1998). Therefore, tolerant plants are able to generate a sufficient amount of energy, maintain membrane permeability and mineral uptake, and even grow in total absence of oxygen (Chirkova, Zhukova, and Goncharova, 1991a; 1992). Moreover, assessment of membrane permeability in an electrolyte leakage test makes it possible to evaluate the degree of plant resistance to oxygen deprivation and other environmental stimuli (Chirkova, Zhukova, and Goncharova, 1991b; Chirkova, Zhukova, Goncharova, and Belonogova, 1991).

\section{Adaptation to post-hypoxic/post-anoxic reoxygenation}

Under reestablishment of a normal oxygen level after hypoxia or anoxia, plants face multiple external challenges affecting plant growth and survival. Fast reentry of oxygen results in oxidation of reduced intermediate and end-products that accumulated during preceding anoxia, soil toxins $\left(\mathrm{Cu}^{+}, \mathrm{Fe}^{2+}, \mathrm{Mn}^{2+}\right)$, overproduction of reactive oxygen species (ROS) and toxic oxidative products (Crawford, 1989; Vartapetian and Jackson, 1997), leading finally to large-scale oxidative post-anoxic stress. Unexpected exposure to higher light may induce photooxidative damage to the photosynthetic apparatus (Tamang and Fukao, 2015). Desiccation of the aboveground part of the plant following reoxygenation is also observed. Weakening of the plant due to the effect of anoxia and post-anoxia may increase the probability of pathogen infection or herbivore attack, since high humidity favors pathogen and phytophage propagation (Tamang and Fukao, 2015).

Nonetheless, oxidative stress is the major challenge during desubmergence or post-anoxic action. We were the first to demonstrate production of hydrogen peroxide (long-living ROS) in plant cells during anoxia and subsequent reoxygenation (Blokhina, Chirkova, and Fagerstedt, 2001). Lipid peroxidation (LPX) begins even under anaerobic conditions and is significantly enhanced upon the return of oxygen to the environment (Chirkova and Blokhina, 1991). Wetland species (Iris pseudacorus, rice) produce a smaller amount of ROS and products of LPX under anoxic and post-anoxic stress than nonresistant ones (I.germanica, oats, wheat, Chirkova, Novitskay, and Blokhina, 1998; Blokhina, Fagerstedt, and Chirkova, 1999). Suppression of oxidative damage in hypoxia-resistant plants correlates with activation of antioxidant enzymes: peroxidase (Chirkova, Sokolovskaya, and Khazova, 1973; Chirkova and Sokolovskaya, 1976; Lastochkin, Yemelyanov, and Chirkova, 2000) and superoxide dismutase (Chirkova, Novitskaya, and Blokhina, 1998), accumulation of tocopherols (Chirkova and Gobedzhishvili, 1993; Chirkova, Novitskaya, and Blokhina, 1998; Blokhina et al., 2000), and turnover of ascorbic acid and glutathione (Blokhina et al., 2000). Thus, hypoxia-resistant plants demonstrate resistance to oxidative stress, too. 


\section{Conclusions}

The study of plant adaptation to oxygen deficiency has been carried out at the Department of Plant Physiology and Biochemistry in Leningrad/Saint Petersburg State University for more than 50 years. Data obtained have been published in more than 100 publications, including 3 textbooks (Chirkova, 1988b; Semikhatova and Chirkova, 2001; Chirkova, 2002). In the course of this research work, more than 80 M.S., 11 Ph.D. and 3 Doctor of Science Theses have been defended. Longterm investigations were summarized in Doctor of Science Theses of T.V.Chirkova (1984), where the scheme of pathways of plant adaptation to oxygen deprivation (Fig. 4) was first suggested. Later it was modified and updated (Chirkova, 1988a,b, 1998); this scheme continues to be developed according to the results of further research.

The pathways of adaptation to oxygen deprivation reflect the general strategy in organism reaction to the effects of various damaging agents (Chirkova, 2002). This strategy consists of, first of all, attempts to avoid an adverse effect; in the case of hypoxia - to avoid oxygen deficiency by the facilitated transport of oxygen into the roots (physiological adaptation) and the formation of associated anatomic-morphologic and developmental adaptations (aerenchyma, superficial adventitious root system, etc.). Avoidance strategy may be realized in both non-tolerant mesophytes and well-adapted wetland plants during soil waterlogging or root flooding. When a plant becomes partially or totally submerged, the avoidance strategy is complemented by growth response. The majority of hydrophyte species respond to submergence by accelerated shoot growth, which facilitates escape from the hypoxic/anoxic environment and constitutes LOES (low-oxygen escape syndrome). Rearrangement of the hormonal network, respiratory metabolism and photosynthesis provide fast underwater growth. Other submergence-tolerant species limit underwater elongation growth and demonstrate quiescent LOQS (low-oxygen quiescence syndrome). These plants react to flooding mostly by metabolic alterations (biochemical adaptation) that become dominant with an increase of the strength of anoxic exposure. Quiescent syndrome involves general decceleration of metabolic rate, providing sufficient carbohydrate supply; compensatory alterations of respiratory, protein and lipid metabolism; anoxic endogenous oxidation; removal and metabolization

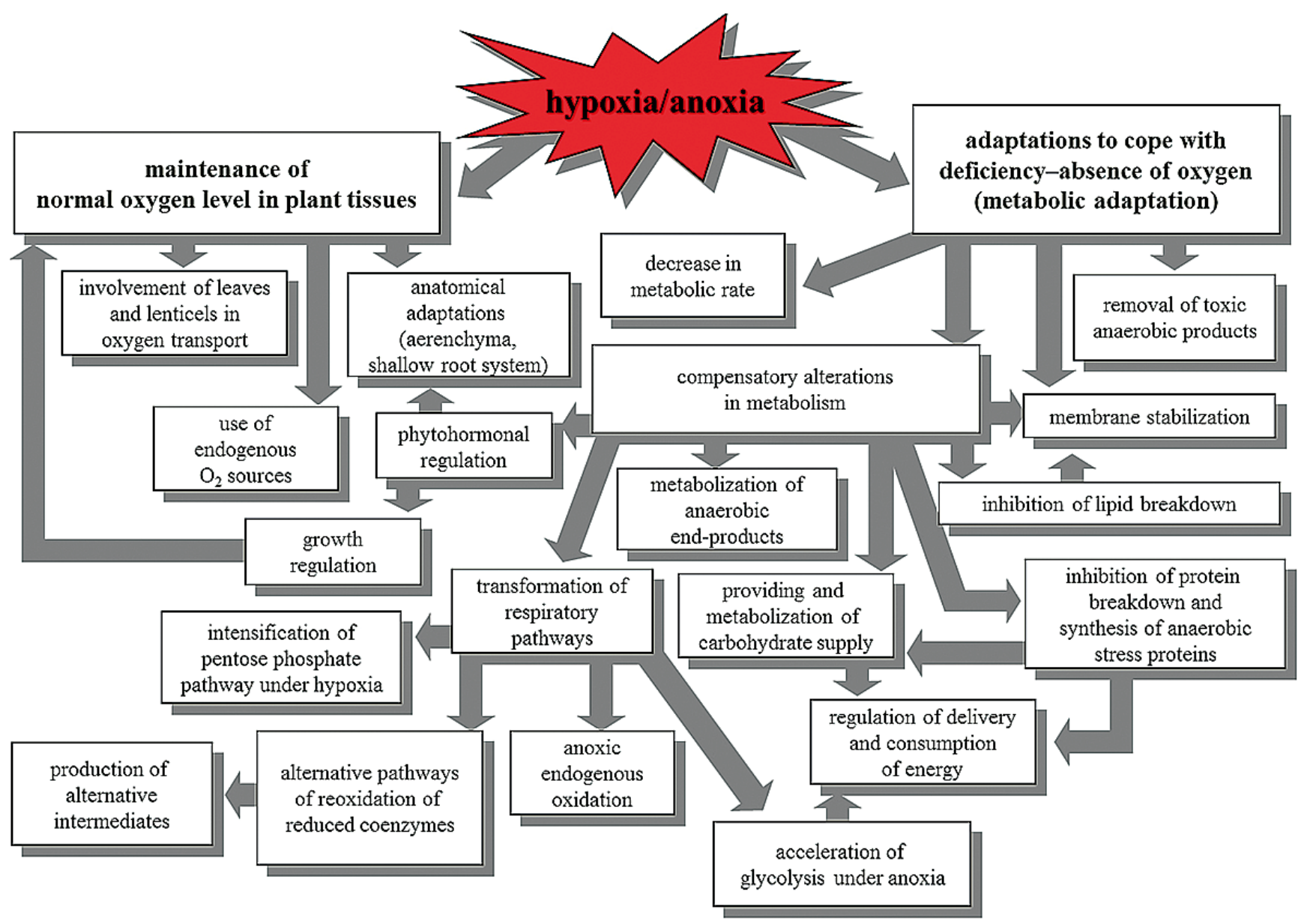

Fig. 4. Scheme of pathways of plant adaptation to oxygen deprivation (Chirkova, 1988a, b, 1998, with modification). 
of toxic anaerobic products; antioxidative defence, etc. The choice of growth responses LOES or LOQS depends on the plant genotype and ambient circumstances, and is governed by ethylene interaction with other plant hormones. LOES is used as an adaptation to long-term flooding in aquatic and semiaquatic habitats by wetland species. LOQS is deployed to survive short-term complete submergence by other hypoxia-resistant plants. Quiescent syndrome ensures preservation of homeostasis and repair of changes upon return to normal aeration conditions. Switching from LOES to LOQS takes place when LOES is incapable of providing successive adaptation due to severe oxygen deficiency or depletion of adaptive capabilities (for non-resistant plants). The combination of different adaptation strategies ensures long-term plant survival in their flood-prone habitat. Non-resistant plants also have a certain set of protective reactions, which are poorly regulated and effective only for short-term adaptation to mild hypoxia. For resistant species the transition from one adaptive strategy to another occurs gradually and provides a longer-term maintenance of metabolism and survival.

\section{References}

Armstrong, W., Brändle, R., and Jackson, M. B. 1994. Mechanisms of flood tolerance in plants. Acta Botanica Neerlandica 43(4):307-358. https://doi. org/10.1111/j.1438-8677.1994.tb00756.x

Bailey-Serres, J. and Voesenek, L. A. C. J. 2008. Flooding stress: acclimations and genetic diversity. Annual Review of Plant Biology 59:313-339. https://doi.org/10.1146/annurev.arplant.59.032607.092752.

Banti, V., Giuntoli, B., Gonzali, S., Loreti, E., Magneschi, L., Novi, G., Paparelli, E., Parlanti, S., Pucciariello, C., Santaniello, A., and Perata, P. 2013. Low oxygen response mechanisms in green organisms. International Journal of Molecular Sciences 14(3):4734-4761. https://doi. org/10.3390/ijms14034734

Belonogova, V.A., and Chirkova, T. V. 1994. Rol' nitratnogo dykhaniya $v$ adaptatsii rasteniy amaranta $\mathrm{k}$ usloviyam zatopleniya [The role of nitrate respiration in adaptation of amaranth plants to flooding conditions]. Biological Communications (3):99-105.

Belonogova, V. A., and Chirkova, T. V. 1995. Vliyanie zatopleniya na metabolizm nitratov $v$ tkanyakh rasteniy pshenitsy i ovsa, razlichayushchikhsya po ustoychivosti k nedostatku kisloroda [Influence of flooding on the metabolism of nitrates in the tissues of wheat and oats, differing in resistance to lack of oxygen]. Agrokhimiya [Agricultural Chemistry] (6):38-46.

Belonogova, V. A., Chirkova, T. V., and Zabruskov, V. G. 1995. Nitratnoe dykhanie i ustoychivost' amaranta argentinskogo k nedostatku kisloroda pri pereuvlazhnenii [Nitrate respiration and the resistance of Amaranthus edulus to oxygen deficiency under flooding]. Biological Communications (4):106-110.

Blokhina, O. B., Chirkova, T. V., and Fagerstedt, K. V. 2001. Anoxic stress leads to hydrogen peroxide formation in plant cells. Journal of Experimental Botany 52(359):11791190. https://doi.org/10.1093/jexbot/52.359.1179

Blokhina, O. B., Fagerstedt, K. V., and Chirkova, T. V. 1999. Relationships between lipid peroxidation and anoxia tol- erance in a range of species during post-anoxic reaeration. Physiologia Plantarum 105(4):625-632. https://doi. org/10.1034/j.1399-3054.1999.105405.x

Blokhina, O. B., Virolainen, E., Fagerstedt, K. V., Hoikkala, A., Wähälä, K., and Chirkova, T. V. 2000. Antioxidant status of anoxia-tolerant and -intolerant plant species under anoxia and reaeration. Physiologia Plantarum 109(4):396403. https://doi.org/10.1034/j.1399-3054.2000.100405.x

Blyudzin, Yu.A., Barskiy, I. E., Chirkova, T. V., and Sokolova, G. P. 1986. Zhirnye kisloty fosfolipidov mitokhondrial'noy i mikrosomal'noy fraktsiy korney prorostkov pshenitsy i risa [Phospholipid fatty acids of mitochondrial and microsomal fractions of roots of wheat and rice seedlings]. Biological Communications (2):85-89.

Blyudzin, Yu.A., Hoang, K. L., and Chirkova, T.V. 1980. Zhirnye kisloty fosfolipidov gomogenata i mitokhondriy korney prorostkov pshenitsy i risa [Phospholipid fatty acids of the homogenate and mitochondria of the roots of wheat and rice seedlings]. Biological Communications (3):92-97.

Chen, Y., Chen, X., Wang, H., Bao, Y., and Zhang, W. 2014. Examination of the leaf proteome during flooding stress and the induction of programmed cell death in maize. Proteome Science 12:33. https://doi.org/10.1186/14775956-12-33

Chirkova, T. V. 1964. Dykhanie korney rasteniy v usloviyakh razlichnoy aeratsii [Respiration of plant roots under different aeration]. Biological Communications (2):127-130.

Chirkova, T. V. 1968a. Puti obespecheniya kornevykh sistem kislorodom [The delivery of additional oxygen to root systems]. Sel'skokhozyaystvennaya Biologiya [Agricultural Biology] 3(3):350-355.

Chirkova, T. V. 1968b. Osobennosti snabzheniya kislorodom korney nekotorykh drevesnykh rasteniy, pomeshchennykh $v$ anaerobnye usloviya [Pecularities of oxygen supply to woody plant roots subjected to anaerobic conditions]. Fiziologiya Rasteniy [Soviet Plant Physiology] 15(3):565-568.

Chirkova, T. V. 1971. Rol' nitratnogo dykhaniya korney $v$ zhiznedeyatel'nosti nekotorykh drevesnykh rasteniy $v$ usloviyakh vremennogo anaerobioza [The role of nitrate respiration of roots in the survival of some woody plants under conditions of temporary anaerobiosis]. Biological Communications (4):118-124.

Chirkova, T. V. 1973. Rol' anaerobnogo dykhaniya v prisposoblenii nekotorykh drevesnykh rasteniy k vremennomu anaerobiozu [The role of anaerobic respiration in the adaptation of some woody plants to temporary anaerobiosis]. Biological Communications (1):88-95.

Chirkova, T. V. 1975. Metabolizm etanola i laktata v tkanyakh drevesnykh rasteniy, razlichayushchikhsya po ustoychivosti k nedostatku kisloroda [Metabolism of ethanol and lactate in the tissues of trees with different resistance to oxygen deficiency]. Fiziologiya Rasteniy [Soviet Plant Physiology] 22(5):952-957.

Chirkova, T.V. 1978. Some regulatory mechanisms of plant adaptation to temporal anaerobiosis; pp. 137-155 in D. D. Hook, R. M. M. Crawford (eds.), Plant life in anaerobic environments. Ann Arbor Science Publishers Inc., Ann Arbor, Michigan, USA.

Chirkova, T. V. 1983. Rol' kletochnykh membran v ustoychivosti rasteniy k gipo- i anoksii [The role of cell membranes in plant resistance to hypo- and anoxia]. Uspekhi sovremennoy biologii 95(1):44-56.

Chirkova, T. V. 1988a. O putyakh prisposobleniya rasteniy $\mathrm{k}$ gipoksii i anoksii [On the pathways of plant adaptation to hypoxia and anoxia]. Fiziologiya Rasteniy [Soviet Plant Physiology] 35(2):393-411. 
Chirkova, T. V. 1988b. Puti adaptatsii rasteniy k gipoksii i anoksii [Pathways of plant adaptation to hypoxia and anoxia]. Leningrad University Press, Leningrad.

Chirkova, T. V. 1998. Rastenie i anaerobioz [Plant and anaerobiosis]. Biological Communications (2):41-52.

Chirkova, T.V. 2002. Fiziologicheskie osnovy ustoychivosti rasteniy. [Physiological basis of plant resistance]. 244 pp. Izdatelstvo Sankt-Peterburgskogo Universiteta, Saint Petersburg

Chirkova, T. V., and Benko, G. N. 1973. Znachenie nitratov v dykhanii korney rasteniy razlichnykh ekologicheskikh grupp v usloviyakh vremennogo anaerobioza [The role of nitrates in the respiration of roots in plants of different ecological groups under the conditions of temporary anaerobiosis]. Sel'skokhozyaystvennaya Biologiya [Agricultural Biology] 8(2):258-262.

Chirkova, T.V., and Blokhina, O. B. 1991. Vliyanie anoksii na uroven' endogennogo perekisnogo okisleniya lipidov $v$ kornyakh rasteniy, razlichayushchikhsya po ustoychivosti $k$ nedostatku kisloroda [Effect of anoxia on the level of endogenous lipid peroxidation in roots of plants, differing in resistance to lack of oxygen]. Biological Communications (4):85-90.

Chirkova, T.V., and Gobedzhishvili, L. O. 1993. Perekisnoe okislenie lipidov i zashchitnaya rol' a-tokoferolatsetata (vitamina E) v list'yakh prorostkov pshenitsy i risa $v$ usloviyakh aeratsii i anoksii [Lipid peroxidation and protective role of a-tocopherol (vitamin E) in leaves of wheat and rice seedlings under normoxic and anoxic conditions]. Biological Communications (1):111-118.

Chirkova, T.V., and Grevnina, G. S. 1982. Vliyanie anaerobnykh usloviy na funktsionirovanie glioksilatnogo tsikla v prorostkakh pshenitsy i risa [Influence of anaerobic conditions on the glyoxylate cycle in seedlings of wheat and rice]. Biological Communications (2):73-78.

Chirkova, T.V., and Gutman, T.S. 1972. O fiziologicheskoy roli chechevichek vetvey ivy i topolya $v$ usloviyakh kornevogo anaerobioza [Physiological role of branch lenticels of willow and poplar under conditions of root anaerobiosis]. Fiziologiya Rasteniy [Soviet Plant Physiology] 19(2):352-359.

Chirkova, T. V., and Hoang, K. L. 1981. Elektroforeticheskie spektry tsitoplazmaticheskikh i mitokhondrial'nykh belkov korney pshenitsy i risa v usloviyakh anaerobioza [Electrophoretic patterns of cytoplasmic and mitochondrial proteins in wheat and rice roots under anaerobiosis]. Fiziologiya Rasteniy [Soviet Plant Physiology] 28(1):136-143.

Chirkova, T. V., and Karpenko, L. A. 1981. Pogloshchenie ksiloroda i redoks-sostoyanie flavinovykh i piridinovykh nukleotidov korney pshenitsy i risa pod vliyaniem ingibitorov transporta elektronov v usloviyakh aeratsii i posle deystviya anaerobioza [Oxygen uptake and redox state of flavin and pyridine nucleotides in roots of wheat and rice treated with inhibitors of electron transport under conditions of aeration and after anaerobiosis]. Biological Communications (1):89-96.

Chirkova, T. V., and Khazova, I. V. 1974. Sootnoshenie putey okisleniya glyukozy pri razlichnom obespechenii rasteniy kislorodom [Ratio of glucose oxidation pathways in plants under different oxygen supply]. Biological Communications (4):111-117.

Chirkova, T.V., and Kovalenko, L.A. 1982. O vozmozhnosti funktsionirovaniya tsianidrezistentnogo dykhaniya v kornyakh pshenitsy i risa posle anaerobnogo vozdeystviya [On the possibility of functioning of cyanide-resistant respiration in the roots of wheat and rice after anaerobic exposure]. Biological Communications (1):74-81.
Chirkova, T.V., and Nastinova, G. E. 1975a. O reparatornoy sposobnosti dykhaniya korney prorostkov pshenitsy $i$ risa posle vozdeystviya usloviy anaerobioza [On the respiratory ability of the roots of wheat and rice seedlings after exposure to anaerobiosis]. Biological Communications (1):104-107.

Chirkova, T. V., and Nastinova, G. E. 1975b. O putyakh okisleniya glyukozy $v$ kornyakh prorostkov pshenitsy i risa v anaerobnykh usloviyakh [On ways of glucose oxidation in roots of wheat and rice seedlings under anaerobic conditions]. Fiziologiya i biokhimiya kul'turnykh rasteniy 7(3):270-274.

Chirkova, T.V., and Nastinova, G. E. 1977. Osobennosti metabolizma $\mathrm{C}^{14}$-glyukozy v kornyakh prorostkov pshenitsy i risa $v$ razlichnykh usloviyakh aeratsii [Metabolism of $\mathrm{C}^{14}$-glucose in the roots of wheat and rice seedlings under various conditions of aeration]. Fiziologiya Rasteniy [Soviet Plant Physiology] 24(2):291-297.

Chirkova, T.V., and Petrova, V. N. 1971. Dykhanie i obmen organicheskikh kislot ivy $\mathrm{i}$ topolya $v$ zavisimosti ot razlichnykh usloviy aeratsii [Respiration and organic acid metabolism of willow and poplar depending on different aeration conditions]. Biological Communications (1):98-106.

Chirkova, T. V., and Semenova, I. N. 1979. Vliyanie etanola na zhiznesposobnost' rasteniy, razlichayushchikhsya po ustoychivosti k kislorodnomu defitsitu, i soderzhanie $\checkmark$ ikh kornyakh belka [Effect of ethanol on viability of plants differing in resistance to oxygen deficiency and on protein content in their roots]. Fiziologiya i biokhimiya kul'turnykh rasteniy 11(1):18-23.

Chirkova, T. V., and Sokolovskaya, E. L. 1976. K voprosu o prichinakh vozrastaniya aktivnosti peroksidazy v kornyakh rasteniy $v$ usloviyakh ogranichennoy aeratsii [To the question of the causes of increase in peroxidase activity in the roots of plants under limited aeration]. Biological Communications (4):123-129.

Chirkova, T.V., and Soldatenkov, S. V. 1965. Puti peredvizheniya kisloroda iz list'ev $v$ korni, nakhodyashchiesya $v$ anaerobnykh usloviyakh [Pathways of movement of oxygen from leaves to roots kept under anaerobic conditions]. Fiziologiya Rasteniy [Soviet Plant Physiology] 12(2):216-225.

Chirkova, T. V., and Voitsekovskaya, S. A. 1999a. Induced synthesis of non-histone chromatin proteins under anoxia. Russian Journal of Plant Physiology 46(4):544-550.

Chirkova, T. V., and Voitsekovskaya, S. A. 1999b. Sintez belka $\mathrm{v}$ rasteniyakh $\mathrm{v}$ usloviyakh gipo- i anoksii [Plant protein synthesis under hypoxia and anoxia]. Uspekhi Sovremennoy Biologii 119(2):178-189.

Chirkova, T. V., and Zhukova, T. M. 1987. Ob osobennostyakh i roli glikoliza $v$ ustoychivosti rasteniy k anaerobnomu vozdeystviyu [The peculiarities and role of glycolysis in plant resistance to anaerobiosis]. Biological Communications (4):61-68.

Chirkova, T. V., Barzhinkova, Z. I., and Hoang, K. L. 1980. Vliyanie etanola na sukhoy i syroy ves i rost korney prorostkov pshenitsy i risa $v$ zavisimost' ot obespecheniya ikh kislorodom [Effect of ethanol on dry and fresh weight and root growth of wheat and rice seedlings in relation to their oxygen supply]. Biological Communications (1):103-108.

Chirkova, T. V., Dragunova, E. V., and Burgova, M.P. 1977. Issledovanie in vivo redoks-reaktsiy flavoproteidov $\mathrm{i}$ piridinnukleotidov korney rasteniy, razlichayushchikhsya po ustoychivosti k nedostatku kisloroda [Redox reactions of flavoproteins and pyridine nucleotides from roots of plants different in their resistance to oxygen de- 
ficiency studied in vivo]. Fiziologiya Rasteniy [Soviet Plant Physiology] 24(1):126-131.

Chirkova, T. V., Hoang, K. L., and Blyudzin, Yu. A. 1981. Vliyanie usloviy anaerobioza na zhirnokislotnyy sostav fosfoliidov korney pshenitsy i risa [Effect of anaerobic conditions on fatty acid composition of wheat and rice root phospholipids]. Fiziologiya Rasteniy [Soviet Plant Physio/ogy] 28(2):358-366.

Chirkova, T. V., Hoang, K. L., and Sinyutina, N. F. 1980. Vozdeystvie etanola na lipidnyy obmen korney prorostkov pshenitsy i risa v razlichnykh usloviyakh gazovogo rezhima [Ethanol effect on lipid metabolism in wheat and rice seedling roots under various gas conditions]. Fiziologiya i biokhimiya kul'turnykh rasteniy 12(1):24-28.

Chirkova, T. V., Karpenko, M. E., and Chernyaeva, E. V. 1992. Vliyanie anaerobioza na pogloshchenie ionov kornyami prorostkov pshenitsy i risa [The effect of anaerobiosis on the ion uptake by the roots of wheat and rice seedlings]. Biological Communications (4):73-78.

Chirkova, T. V., Khazova, I. V., and Astafurova, T. P. 1974. K voprosu o metabolicheskoy regulyatsii prisposobleniya rasteniy $\mathrm{k}$ usloviyam vremennogo anaerobioza [On metabolic regulation of plant adaptation to temporal anaerobiosis]. Fiziologiya Rasteniy [Soviet Plant Physiology] 21(1):102-107.

Chirkova, T. V., Nastinova, G. E., and Semenova, I. N. 1978. Puti detoksikatsii produktov anaerobnogo obmena $v$ kornyakh rasteniy, razlichayushchikhsya po ustoychivosti k kislorodnomu defitsitu [Pathways of the anaerobic metabolism products detoxification in roots of plants differing in resistance to oxygen deficiency]. Fiziologiya $i$ biokhimiya kul'turnykh rasteniy 10(5):469-475.

Chirkova, T.V., Nastinova, G. E., and Zhukova, T. M. 1978. Vliyanie ingibitorov sinteza belka na soderzhanie belka i aktivnost' alkogol'- i laktatdegidrogenaz v kornyakh pshenitsy i risa v raznykh usloviyakh aeratsii [The effect of protein synthesis inhibitors on the protein content and the activity of alcohol and lactate dehydrogenases in wheat and rice roots under different aeration conditions]. Biological Communications (2):120-126.

Chirkova, T. V., Novitskaya, L. O., and Blokhina, O. B. 1998. Lipid peroxidation and antioxidant systems under anoxia in plants differing in their tolerance to oxygen deficiency. Russian Journal of Plant Physiology 45(1):55-62.

Chirkova, T. V., Sokolovskaya, E. L., and Khazova, I. V. 1973. Aktivnost' i izofermentnyy sostav peroksidazy korney rasteniy $v$ zavisimosti ot usloviy vremennogo anaerobioza [Effect of temporal anaerobiosis on the activity and isoenzyme composition of peroxidase in plant roots]. Fiziologiya Rasteniy [Soviet Plant Physiology] 20(6):12361241.

Chirkova, T. V., Surodeeva, E. K., and Semenova, L. L. 1986. Vliyanie anaerobioza na sostav negistonovykh belkov khromatina prorostkov pshenitsy i risa [Influence of anaerobiosis on the composition of non-histone proteins in wheat and rice seedling chromatin]. Fiziologiya Rasteniy [Soviet Plant Physiology] 33(5):979-986.

Chirkova, T. V., Zhukova, T. M., and Goncharova, N. N. 1991a. Osobennosti pronitsaemosti membran korney prorostkov pshenitsy i risa v usloviyakh anaerobioza [Peculiarities of membrane permeability of wheat and rice seedling roots under anaerobic condition]. Fiziologiya i biokhimiya kul'turnykh rasteniy 23(6):541-546.

Chirkova, T. V., Zhukova, T. M., and Goncharova, N. N. 1991b. Sposob opredeleniya ustoychivosti rasteniy k nedostatku kisloroda [A method for defining plant tolerance to oxygen deficiency]. Fiziologiya Rasteniy [Soviet Plant Physiology] 38(2):359-364.
Chirkova, T. V., Zhukova, T. M., and Ivanova, E. A. 1984. Aktivnost' adenilatkinazy $v$ kornyakh prorostkov pshenitsy i risa $v$ usloviyakh aeratsii i posle anaerobnogo vozdeystviya [Activity of adenylate kinase in roots of wheat and rice seedlings under conditions of aeration and after anaerobic action]. Fiziologiya i biokhimiya kul'turnykh rasteniy 16(4):329-335.

Chirkova, T. V., Barkova, I. G., Barzhinkova, Z. I., and Magomedov, I. M. 1985. Dikarbonovye organicheskie kisloty korney pshenitsy i risa v usloviyakh aeratsii i anaerobioza [Dicarboxylic organic acids in the roots of wheat and rice under aeration and anaerobiosis]. Biological Communications (4):48-56.

Chirkova, T. V., Barzhinkova, Z. I., Barkova, I. G., and Magomedov, I. M. 1984. Malatdegidrogenaza korney pshenitsy i risa v usloviyakh aeratsii i posle anaerobnogo vozdeystviya [Malate dehydrogenase in the roots of wheat and rice under aeration and after anaerobic action]. Biological Communications (4):59-68.

Chirkova, T. V., Gobedzhishvili, L. O., Hakala, K.-L., and Sinyutina, N. F. 1991a. Vliyanie anaerobioza na metabolizm fosfolipidov khloroplastov prorostkov pshenitsy i risa [Influence of anaerobiosis on the metabolism of phospholipids in chloroplasts of wheat and rice seedlings]. Biological Communications (2):77-82.

Chirkova, T. V., Gobedzhishvili, L. O., Hakala, K.-L., and Sinyutina, N. F. 1991b. Vliyanie anaerobioza i temnoty na metabolizm galaktolipidov khloroplastov prorostkov pshenitsy i risa [Effect of anaerobiosis and darkness on the metabolism of galactolipid in chloroplasts of wheat and rice seedlings]. Biological Communications (3):88-96.

Chirkova, T.V., Novitskaya, L. O., Walter, G., and Leffer, S. 1995. Vliyanie anaerobioza i dlitel'noy temnoty na soderzhanie belka v list'yakh prorostkov pshenitsy i risa [The influence of anaerobiosis and long darkening upon the protein content in the leaves of wheat and rice seedlings]. Biological Communications (3):96-103.

Chirkova, T. V., Saakov, V.S., Semenova, A. V., and Avdeeva, A.V. 1993. The effect of anoxia on the structural and biochemical properties of mitochondrial proteins in the roots of wheat and rice seedlings. Russian Journal of Plant Physiology 40(4):563-567.

Chirkova, T.V., Sinyutina, N.F., Smetannikova, S. V., and Krynkina, E. N. 1989. Vliyanie anoksii na vklyuchenie ${ }_{1-14}{ }^{14}$-atsetata $v$ fosfolipidy mitokhondriy i mikrosom korney pshenitsy i risa [Effect of anoxia on the incorporation of $1-{ }^{14} \mathrm{C}$-acetate into phospholipids of mitochondria and microsomes in roots of wheat and rice]. Biological Communications (3):76-82.

Chirkova, T. V., Verzilin, N. N., Barzhinkova, Z. I., and Petryaevskaya, T. G. 1981. Vliyanie usloviy anaerobioza na sdvigi $\mathrm{pH}$ v kornyakh pshenitsy i risa [Effect of anaerobic conditions on $\mathrm{pH}$ shifts in wheat and rice roots]. Fiziologiya $i$ biokhimiya kul'turnykh rasteniy 13(6):587-593.

Chirkova, T.V., Walter, G., Leffer, S., and Novitskaya, L. O. 1995. Chloroplasts and mitochondria in the leaves of wheat and rice seedlings exposed to anoxia and longterm darkness: some characteristics of organelle state. Russian Journal of Plant Physiology 42(3):321-329.

Chirkova, T. V., Zhukova, T. M., Goncharova, N. N., and Belonogova, V. A. 1991. Opredelenie stepeni pronitsaemosti membran kak sposob diagnostiki rasteniy na ustoychivost' k nedostatku kisloroda [Determination of the membrane permeability level as the method of plant diagnostic for resistance to oxygen dificiency]. Fiziologiya $i$ biokhimiya kul'turnykh rasteniy 23(1):68-75.

Chirkova, T. V., Sinyutina, N. F., Blyudzin, Yu.A., Barsky, I. E., and Smetannikova, S. V. 1989. Zhirnye kisloty fosfolipidov mi- 
tokhondriy i mikrosom korney prorostkov pshenitsy i risa pri aeratsii i anaerobioze [Phospholipid fatty acids of root mitochondria and microsomes from rice and wheat seedlings exposed to aeration or anaerobiosis]. Fiziologiya Rasteniy [Soviet Plant Physiology] 36(1):126-134.

Crawford, R. M. M. 1978. Metabolic adaptation to anoxia; pp. 119-136 in D. D. Hook, R. M. M. Crawford (eds.), Plant life in anaerobic environments. Ann Arbor Science Publishers Inc., Ann Arbor, Michigan, USA.

Crawford, R. M. M. 1989. Studies in plant survival. Ecological case histories of plant adaptation to adversity; 296p. in D. J. Anderson, P. Greic-Smith, F. A. Pitelka (eds.), Studies in ecology. Vol. 11. Blackwell Scientific Publications, Oxford - London - Edinburgh - Boston - Palo Alto Melbourne.

Crawford, R. M. M., and Braendle, R. 1996. Oxygen deprivation stress in a changing environment. Journal of Experimental Botany 47(295):145-159. https://doi.org/10.1093/ jxb/47.2.145

Dennis, E. S., Dolferus, R., Ellis, M., Rahman, M., Wu, Y., Hoeren, F. U., Grover, A., Ismond, K.P., Good, A. G., and Peacock, W. J. 2000. Molecular strategies for improving waterlogging tolerance in plants. Journal of Experimental Botany 51(342):89-97. https://doi.org/10.1093/jexbot/51.342.89

Drew, M. C. 1997. Oxygen deficiency and root metabolism: injury and acclimation under hypoxia and anoxia. Annual Review of Plant Physiology and Plant Molecular Biology 48:223-250. https://doi.org/10.1146/annurev.arplant.48.1.223

Emel'yanov, V.V., Kirchikhina, N.A., Lastochkin, V. V., and Chirkova, T.V. 2003. Hormonal status in wheat and rice seedlings under anoxia. Russian Journal of Plant Physiology 50(6):827-834. https://doi.org/10.1023/ B:RUPP.0000003282.26789.6b

Fukao, T., and Bailey-Serres, J. 2008. Submergence tolerance conferred by Sub1A is mediated by SLR1 and SLRL1 restriction of gibberellin responses in rice. Proceedings of the National Academy of Sciences of USA 105(43):1681416819. https://doi.org/10.1073/pnas.0807821105

Fukao, T., Xu, K., Ronald, P. C., and Bailey-Serres, J. 2006. A variable cluster of ethylene response factor-like genes regulates metabolic and developmental acclimation responses to submergence in rice. Plant Cell 18(8):20212034. https://doi.org/10.1105/tpc.106.043000

Hoang, K. L., Sinyutina, N. F., and Chirkova, T. V. 1979. Vliyanie usloviy anaerobioza na lipidnyy i belkovyy obmen korney pshenitsy i risa [Influence of anaerobiosis on the lipid and protein metabolism in wheat and rice roots]. Fiziologiya Rasteniy [Soviet Plant Physiology] 26(3):606-612.

Hu, Z., Qi, X., Zhang, M., Chen, X., and Nakazono, M. 2016. Roles of phytohormones in morphological and anatomical responses of plants to flooding stress. pp. 117132. in G.J. Ahammed, J.-Q. Yu (eds.), Plant Hormones under Challenging Environmental Factors. Springer Science+Business Media, Dordrecht. https://doi. org/10.1007/978-94-017-7758-2_5

Igamberdiev, A. U., and Hill, R.D. 2009. Plant mitochondrial function during anaerobiosis. Annals of Botany 103(2):259-268. https://doi.org/10.1093/aob/mcn100

Kende, H., van der Knaap, E., and Cho, H.-T. 1998. Deepwater rice: A model plant to study stem elongation. Plant Physiology 118(4):1105-1110. https://doi.org/10.1104/ pp.118.4.1105

Kostychev, S.P. 1907. Issledovanija nad anajerobnym dyhaniem rastenij [Studies on anaerobic respiration of plants]. Botanicheskie zapiski pri Botanicheskom sade
Sankt-Peterburgskogo Universiteta [Botanical Notes at the Botanical Garden of St. Petersburg University] (25):1-162.

Kulichikhin, K. Y., Chirkova, T. V., and Fagerstedt, K. V. 2009. Activity of biochemical pH-stat enzymes in cereal root tips under oxygen deficiency. Russian Journal of Plant Physiology 56(3)377-388. https://doi.org/10.1134/ S102144370903011X

Kulichikhin, K. Yu., Kurchakova, E. V., and Chirkova, T. V. 2000. Aktivnost' malatdegidrogenazy i soderzhanie endogennogo malata v kornyakh zlakov v usloviyakh anoksii [The activity of malate dehydrogenases and endogenous malate content in roots of cereals under anoxic conditions]. Biological Communications (3):70-76.

Kulichikhin, K. Y., Aitio, O., Chirkova, T. V., and Fagerstedt, K. V. 2007. Effect of oxygen concentration on intracellular $\mathrm{pH}$, glucose-6-phosphate and NTP content in rice (Oryza sativa) and wheat (Triticum aestivum) root tips: In vivo ${ }^{31}$ P-NMR study. Physiologia Plantarum 129(3):507-518. https://doi.org/10.1111/j.1399-3054.2006.00819.x

Lastochkin, V. V., Yemelyanov, V. V., and Chirkova, T. V. 2000. Aktivnost' peroksidazy $v$ prorostkakh pshenitsy i risa $\mathrm{v}$ svyazi s vozdeystviem anoksii [Peroxidase activity in wheat and rice seedlings under anoxia]. Biological Communications (3):59-64.

Licausi, F. and Perata, P. 2009. Low oxygen signaling and tolerance in plants. Advances in Botanical Research 50:139198. https://doi.org/10.1016/S0065-2296(08)00804-5

Licausi, F., Weits, D. A., Pant, B. D., Scheible, W.-R., Geigenberger, P., and van Dongen, J. T. 2011. Hypoxia responsive gene expression is mediated by various subsets of transcription factors and miRNAs that are determined by the actual oxygen availability. New Phytologist 190(2):442456. https://doi.org/10.1111/j.1469-8137.2010.03451.x

Nabokikh, A. I. 1905. Vremennyj anajerobioz vysshih rastenij: Eksperimental'noe issledovanie. Chast' 1. Nabljudenija nad processami rosta $v$ beskislorodnoj srede. [Temporary anaerobiosis of higher plants: Experimental study. Part 1. Observations on growth processes in an oxygenfree environment.] St. Petersburg: Publishing house of I. N. Skorokhodov

Nastinova, G. E., and Chirkova, T. V. 1978. O vozmozhnosti sinteza alkogol'- i laktatdegidrogenaz pri nedostatke kisloroda [On the possibility of synthesis of alcohol and lactate dehydrogenases in conditions of oxygen deficiency]. Fiziologiya Rasteniy [Soviet Plant Physiology] 25(1):55-63.

Nishiuchi, S., Yamauchi, T., Takahashi, H., Kotula, L., and Nakazono, M. 2012. Mechanisms for coping with submergence and waterlogging in rice. Rice 5(1):2 https://doi. org/10.1186/1939-8433-5-2

Pedersen, O., Colmer, T. D., and Sand-Jensen, K. 2013. Underwater photosynthesis of submerged plants - recent advances and methods. Frontiers in Plant Science 4:140. https://doi.org/10.3389/fpls.2013.00140

Pedersen, O., Rich, S. M., and Colmer, T. D. 2009. Surviving floods: leaf gas films improve $\mathrm{O}_{2}$ and $\mathrm{CO}_{2}$ exchange, root aeration, and growth of completely submerged rice. Plant Journal 58(1):147-156. https://doi.org/10.1111/ j.1365-313X.2008.03769.x

Peeters, A.J.M., Cox, M.C.H., Benschop, J.J., Vreeburg, R. A. M., Bou, J., and Voesenek, L. A. C. J. 2002. Submergence research using Rumex palustris as a model; looking back and going forward. Journal of Experimental Botany 53(368):391-398. https://doi.org/10.1093/jexbot/53.368.391

Sauter, M. and Steffens, B. 2014. Biogenesis of adventitious roots and their involvement in the adaptation to oxygen limitations; pp. 299-312. in J. T.van Dongen and F. Licausi (eds.), Low-Oxygen Stress in Plants, Plant Cell 
Monographs. Vol. 21. Springer-Verlag, Wien. https://doi. org/10.1007/978-3-7091-1254-0_15

Schmitz, A. J., Folsom, J. J., Jikamaru, Y., Ronald, P., and Walia, H. 2013. SUB1A-mediated submergence tolerance response in rice involves differential regulation of the brassinosteroid pathway. New Phytologist 198(4):10601070. https://doi.org/10.1111/nph.12202

Semikhatova, O.A., and Chirkova, T.V. 2001. Fiziologiya dykhaniya rasteniy. [Physiology of plant respiration]. Izdatelstvo Sankt-Peterburgskogo Universiteta, Saint Petersburg, $220 \mathrm{pp}$.

Sinyutina, N. F., Hoang, K. L., and Chirkova, T. V. 1979. Fosfolipidy korney pshenitsy i risa $v$ svyazi s razlichnym obespecheniem rasteniy kislorodom [Phospholipids of the roots of wheat and rice in realtion to various oxygen level]. Biological Communications (4):93-98.

Soldatenkov, S. V. and Chirkova, T. V. 1963. O roli list'ev v dykhanii korney, lishennykh kisloroda [Role of leaves in respiration of roots deprived of oxygen]. Fiziologiya Rasteniy [Soviet Plant Physiology] 10(5):535-543.

Soldatenkov, S. V. and Zhao, X.-D. 1961. Rol' list'ev fasoli i kukuruzy $v$ dykhanii korney, lishennykh kisloroda [Role of bean and maize leaves in the respiration of roots deprived of oxygen]. Fiziologiya Rasteniy [Soviet Plant Physiology] 8(4):385-394.

Takahashi, H., Yamauchi, T., Colmer, T. D., and Nakazono M. 2014. Aerenchyma formation in plants; pp. 247-265. in J. T. van Dongen and F. Licausi (eds.), Low-Oxygen Stress in Plants, Plant Cell Monographs. Vol. 21. Springer-Verlag, Wien. https://doi.org/10.1007/978-3-7091-1254-0_13

Tamang, B. G., and Fukao, T. 2015. Plant adaptation to multiple stresses during submergence and following desubmergence. International Journal of Molecular Sciences 16(12):30164-30180. https://doi.org/10.3390/ ijms161226226

Valyavskaya M. V., Sinyutina N. F., Chirkova T. V. 2000. Vliyanie ionov kal'tsiya na soderzhanie lipidov $v$ kornyakh pshenitsy i risa $v$ usloviyakh anaerobioza [Influence of $\mathrm{Ca}^{2+}$ ions on lipid content in the roots of weat and rice under anoxia]. Biological Communications (4):32-38.

Valyavskaya, M. V., Sinyutina, N. F., and Chirkova, T. V. 2002. Vliyanie ionov kal'tsiya na izmenenie soderzhaniya lipidov mitokhondriy pri anoksii u rasteniy s razlichnoy ustoychivost'yu $\mathrm{k}$ nedostatku kisloroda [Influence of $\mathrm{Ca}^{2+}$ ions and anoxia on lipid content of mitochondrial membranes in plants with different resistance to oxygen insufficiency]. Biological Communications (2):48-54.

Vartapetian B. B., and Jackson, M. B. 1997. Plant adaptations to anaerobic stress. Annals of Botany 79(Special Issue):3-20. https://doi.org/10.1093/oxfordjournals.aob. a010303

Voesenek, L. A. C. J., and Bailey-Serres, J. 2015. Flood adaptive traits and processes: an overview. New Phytologist 206(1):57-73. https://doi.org/10.1111/nph.13209

Voitsekovskaya, S. A., and Chirkova, T. V. 1992. O vozmozhnosti sinteza negistonovykh belkov khromatina $v$ pro- rostkakh pshenitsy i risa pri otsutstvii kisloroda [On the possibility of synthesis of non-histone chromatin proteins in wheat and rice seedlings under the absence of oxygen]. Biological Communications (3):73-79.

Voitsekovskaya, S. A., Badyina, T. G., and Chirkova, T. V. 1993. Vliyanie anaerobioza na svoystva khromatina i sostav ego negistonovykh belkov $v$ prorostkakh pshenitsy $i$ risa [Effect of anaerobiosis on chromatin properties and composition of non-histone proteins of chromatin in seedlings of wheat and rice]. Fiziologiya $i$ biokhimiya kul'turnykh rasteniy 25(1):58-66.

Watanabe, K., Nishiuchi, S., Kulichikhin, K., and Nakazono, M. 2013. Does suberin accumulation in plant roots contribute to waterlogging tolerance? Frontiers in Plant Science 4:178. https://doi.org/10.3389/fpls.2013.00178

Winkel, A., Colmer, T. D., Ismail, A. M., and Pedersen, O. 2013. Internal aeration of paddy field rice (Oryza sativa) during complete submergence - importance of light and floodwater $\mathrm{O}_{2}$. New Phytologist 197(4):1193-1203. https://doi. org/10.1111/nph.12048

Winkel, A., Pedersen, O., Ella, E., Ismail, A. M., and Colmer, T. D. 2014. Gas film retention and underwater photosynthesis during field submergence of four contrasting rice genotypes Journal of Experimental Botany 65(12):3225-3233. https://doi.org/10.1093/jxb/eru166

Yemelyanov V. V. 1998. Rost i gormony rasteniy v usloviyakh anaerobioza [Plant growth and hormones under anaerobiosis]. Biological Communication (2):136-140.

Yemelyanov, V. V., and Chirkova, T. V. 1996. Svobodnye formy gormonov $v$ rasteniyakh, razlichayushchikhsya po ustoychivosti k nedostatku kisloroda, v usloviyakh aeratsii i anaerobioza [Free forms of phytohormones in plants with different tolerance to the lack of oxygen under aeration and anaerobiosis]. Biological Communications (2):73-81

Yemelyanov, V. V., and Shishova, M. F. 2012. The role of phytohormones in the control of plant adaptation to oxygen depletion; pp. 229-248 in N. A. Khan, R. Nazar, A. Iqbal, N.A. Anjum (eds.), Phytohormones and abiotic stress tolerance in plants. Springer-Verlag, Berlin-Heidelberg. https://doi.org/10.1007/978-3-642-25829-9_10

Yin, X., Sakata, K., Nanjo, Y., Komatsu, S. 2014. Analysis of initial changes in the proteins of soybean root tip under flooding stress using gel-free and gel-based proteomic techniques. Journal of Proteomics 106:1-16. https://doi. org/10.1016/j.jprot.2014.04.004

Zhukova, T. M. 1987. Vliyanie anaerobioza na soderzhanie uglevodov $v$ kornyakh prorostkov pshenitsy i risa [The effect of anaerobiosis on the carbohydrate content in the roots of wheat and rice seedlings]. Biological Communications (2):88-93.

Zhukova, T. M., Chirkova, T. V., and Tretyakov, A. V. 1984. Adeninovye nukleotidy prorostkov pshenitsy i risa $v$ razlichnykh usloviyakh aeratsii [Adenine nucleotides in seedlings of wheat and rice under different aeration conditions]. Biological Communications (3):74-81. 